Journal of CORPORATE RESPONSIBILITY

AND LEADERSHIP

Positive Leadership and Management

\title{
Leadership Characters in the Book of Ruth: A Narrative Analysis
}

DOI: http://dx.doi.org/10.12775/JCRL.2016.016

\author{
YONG LU \\ Institute of Psychology, Faculty of Christian Philosophy, \\ Cardinal Stefan Wyszyński University in Warsaw, Poland \\ e-mail: luyong@student.uksw.edu.pl
}

\begin{abstract}
This article delineates a ground work for shaping Christian leadership characters by examining the book of Ruth, a narrative of cooperation. First, we introduce the general Biblical wisdom, guidance, and religious precepts on leadership characters from the Bible per se. Second, we depict a synopsis and connotation of the Ruth Narrative combined with the historical background of the late Judges time when Naomi, Elimelech, Ruth and Boaz lived and the social and religious background of Moab where the family of Elimelech dwelt in for ten years. Third, based on those background analyses, the main figures' dialogues, and their actions, we illustrate their positive servant and mentor leadership characters that include a combination of their distinguished traits and cognitive attributes, as well as some weaknesses of Naomi and Elimelech. In a nutshell, Naomi's leadership characters contain loyalty to God (2:19-20), discovering value within (3:1-4), and patience and endurance (3:18). Ruth's leadership characters incorporate faithfulness and positive self-esteem (1:16-17), pioneer and daring (2:2), deference (2:10), obedience (3:5), and loving-kindness (3:10). Boaz's leadership characters include respect (2:4), care (2:5), compassion (2:8-9, 11), empowerment (2:15-16), leaning on and trusting God (2:12), care (2:14; 3:15), protecting the weak (3:10-15), responsibility (3:12), moral integrity and justness (3:13), carefulness (3:14), formation (4:1), unselfishness and cleverness (4:3-5), and partnering (4:9-10). While we criticize Elimelech's risk seeking strategy to migrate their family to a pagan country $(1: 1-2)$ as a spiritual adventure.
\end{abstract}

I Keywords: leadership characters, Bible, the Book of Ruth. 


\section{Introduction}

The Bible is an essential and inspired source of authority and power for learning of excellent Christian leadership, though which main purpose is to build relationships between humans and God. Some scholars propose to develop the existing Christian leadership research much more theologically and practically than secularly and organisationally (Huizing, 2011).

In order to establish a fruitful leadership from the perspective of Jesus Christ's teaching that "the one who rules like the one who serves" (Luke 22:26), a spiritually matured Christian leader should bear in mind the understanding that, in short, building the mutual friendly relationship and that serving for others are God's wishes for His people. Therefore, promoted by the Scripture to emphasize the greatest opportunity to honour God and a necessary balance between morality and mission achievement, scholars have inoculated a new division of leadership studies, servant leadership (see Irving, 2011; Niewold, 2007; Roberts, 2015, p. 1-68; and Wilkes, 2008 for a detailed explanation on Christian servant leadership; see also Serrano, 2014 for a discussion on the differences between servant leadership and charismatic leadership). Servant leader not only accomplishes great goals by lording it over others, but also rather by serving others. Furthermore, servant leader's love and character virtue could generate favourably attitudinal and behavioural outcomes with regard to performance of an individual and a group as well as well-being of an employee and community. In a result, more and more both Christian and secular authorities, organisations, families, and employers have admitted Jesus Christ's this servant principle as the Golden Rule in practice in against the so-called real "Golden Rules" of business: "Those who have the gold make the rules" and "Serve to others before they can serve to you."

Jesus Christ Himself is the best-known servant leader in the Bible (e.g., Acts 3:13, 4:27, 30; Romans 15:8). When the mother of Zebedee's sons asked their privileged seats in the kingdom, Jesus declares that "Instead, whoever wants to become great among you must be your servant, and whoever wants to be first must be your salve - just as the Son of Man did not come to be served, but to serve, and to give his life as a ransom for many" (Matthew 20:26-27). Other examples for Jesus Christ's acting as a servant include washing His disciples' feet 
(John 13:3-9), coming to dwell among humanity as a man (Philippians 2:6-7), and ministering to His disciples (John 13:1-17).

On the other hand, another leadership relationship in the Bible is also often seen, in which a more experienced mentor works to prompt the personal and professional growth of a less experienced protégé. For example, Hoehl (2011) discussed Paul as Timothy's loving mentor: Paul firstly chose Timothy carefully as his co-worker in the ministry as Timothy was the son of a believing Jewess with high reputation among people (Acts 16:1-3) and a good spiritual heritage from his mother (2 Timothy 1:5, 3:15), secondly equipped and trained him for ministerial tasks (Acts 17:14), then assigned him to accomplish a challenging work (Acts 18:1-5), and finally trained him as a successful church leader (Philippians 2:19-23).

The legendary kings, prophets, strategists, and warriors in the Scriptures not only give us good examples on effective strategies as well as even some failed negative tactics, but also teach us the pious characters and traits of their leadership, such as integrity, honesty, kindness, compassion, share, humility, and communication skills, with which a successful contemporary leader should be also endowed (for practicability of Biblical leadership in modern management business, see Woolfe, 2002 for some illustrations). In the following, we take those precious characters and traits in the Bible for example.

People followed their spiritual leader, Moses, since he was a man of great integrity against lying, stealing, and betraying to God (Exodus 2-20). Zacchaeus probably was not a leader among his people since he pursued the least popular profession in ancient Israel as a tax collector. However, he found his lost integrity again and therefore got salvation after he promised to give back half of his possessions to the poor and would pay anybody back four times the amount if he cheated the one out of anything (Luke 19: 1-8; cf. Judas Iscariot's lack of integrity for greed).

Lot probably was a good leader who wanted to save the people living in Sodom, although those wicked people were all against him. As a result, he was saved from the burning sulphur of Sodom and Gomorrah for his honesty (Genesis 19). The Bible specifically teaches us honesty: "Do not have two differing weights in your bag - one heavy, one light. Do not have two differing measures in your house - one large, one small. You must have accurate and honest weights and measures, 
so that you may live long in the land the Lord your God is giving you" (Deuteronomy 25:13-15).

Jesus Christ is undoubtedly a spiritual leader, and we can always learn from His compassion on the sinful, the lost, and the spiritually dead: "His father saw him and was filled with compassion for him" (Luke 15:20), on the sick: "When Jesus landed and saw a large crowd, he had compassion on them and healed their sick" (Matthew 14:14), on the hungry multitude: "I have compassion for these people: they have already been with me three days and have nothing to eat" (Mark 8:2), and on the disabled: "Jesus had compassion on them and touched their eyes" (Matthew 20:34; see also Mark 1:40-41). David showed his compassion when conquering his vengefulness in remembrance of Jonathan's kindness. Finally, David chose to overlook the treacherousness of Saul: "Don't be afraid, for I will surely show your kindness for the sake of your father Jonathan. I will restore to you all the land that belonged to your grandfather Saul, and you will always eat at my table” (2 Samuel 9:7).

Jesus Christ also shows His kindness on the sinful: "Be love your enemies, and do good, and lend, expecting nothing in return; and your reward will be great, and you will be sons of the Most High; for He Himself is kind to ungrateful and evil men" (Luke 6:35; also see John 3:16). Daniel bravely prompted King Nebuchadnezzar of Babylonia "being kind to the oppressed" in Daniel 4:27 (Thomas, 2014). The apostle Paul also teaches us to "be kind and compassionate to one another" (Ephesians 4:32) and to "clothe yourselves with compassion and kindness" (Colossians 3:12).

Sharing the wealth is also a Biblical golden premise for a good leader. We can find the teaching from a very straightforward passage in the Bible: "The man with two tunics should share with him who has none, and the one who has food should do the same" (Luke 3:11, 6:38). An empirical evidence has proved that when you give, you will be given back in multiples (e.g., the Thyatira business woman Lydia invited Paul and his co-workers staying in her house, and she and her household were baptized, see Acts 16:13-15).

Humility is a precious leadership character which was magnificent in Moses who accomplished securing his people from Pharaoh's powerful lead to the freedom (as for how God molded Moses to be a prototype of spiritual leadership, see Whittington, 2015, p. 29-63). As a successful leader, Moses "was a very humble man, more humble than 
anyone" (Numbers 12:3). Jesus Christ also teaches us that "therefore anyone who becomes as humble as this little child is the greatest in the kingdom of heaven” (Matthew 18:4).

Effective, clear and powerful communication is very crucial for a leader of the Bible. Jesus, Moses, David, and Paul, for example, were all skilled communication masters, preachers, and organisers for group meetings even in a hostile environment in front of a mass of people and secular authorities (also see McNeal, 2011, p. 3-71 for how God shaped their hearts for leadership).

Although large accumulated research has studied leaders' characters, their arguments are mainly underpinned from secular viewpoints, and those leadership characters in the Bible, especially women's, have not been emphasized so far in the literature (for those limited research, see e.g., McNeal, 2011; Roberts, 2015; Whittington, 2015; Wilkes, 2008). Furthermore, in consideration of the book of Ruth which is not only one of the Bible's best-known and most-loved narrative conveying important theological themes, but also is full of excellent leadership characters and wisdoms from especially women, the present paper aims to delineate a ground work for shaping Christian leadership characters in the book. In the following, we propose an exposition of this beloved Narrative based on an analysis of the social historical background depicted at that time (i.e., the late Judge time) and their living places (i.e., Judah and Moab) that comprises such as social identities between the marriages of the Moabite and the Israelite, ethnic groups, and contrast of social economics. According to McNeal (2011, p. 73-92), those social and historical circumstances may influence people's characters, cognitions, responses, behaviours, and words. Furthermore, we illustrate some suggestions about the distinguished leadership characters of Naomi, Ruth, Boaz, and Elimelech, as well as some weaknesses of Naomi's strategies and Elimeleh's spiritual risk seeking behaviours.

\section{A synopsis of the Book of Ruth}

The book of Ruth sheds light on some purposeful resonance with the story in Genesis 38 and the legal customs in Deuteronomy 25 (see Green, 1982 for a detailed account). In the first beginning, the narrative describes that a famine in Bethlehem of Israel broke out in the time of the Judges (1:1). From reading the history of that time in Judges 
2:10-23 and 21:25, a much disordered period after Moses and Joshua and before that Israel had a king Saul, we can deduce that the reason for the famine is probably because people did not care what God indicated them to do and did anything they thought was right.

"Bethlehem" means "house of bread." Although it is ironic that the people living in the house of bread had to flee to a foreign country because of famine, life's situations which belie the title of a place or a person (e.g., Naomi's name which means "Pleasant" or "My Pleasantness") often happen.

The author refers to the historical period in the opening sentence of Ruth, "in the days when the judges ruled" (1:1a), which can also be contrasted to the social situation described in the end of the book of Judges. The late Judges period was a chaotic time, and people were victims. While in the book of Ruth, the society run in an orderly and responsible fashion. Both Judges and Ruth are advocates for Davidic kingship.

A man, Elimelech ("Elimelech" means "My God is King”), his Jewish wife, Naomi, and their two sons, Mahlon ("Mahlon" means "Sick") and Kilion (or Chilion; "Kilion” means "Lonely”), from Bethlehem-Judah together went to live in the country of Moab for a while (1:1-2). Moab is named after the older daughter's son of Lot, Abraham's nephew, and was conceived in Lot's drunken incest with his daughter (for the story, see Genesis 19:30-38).

During the late Judges time, The Scripture presents the land of Moab as being consistently fertile, and the Judahite famine and other disasters have not influenced it. Moab's and Judah's territorial boundaries - social, cultural, or geo-political - are construed neutrally in the Ruth narrative as a sign of cooperation and nurture, rather than of a competing or conflicting contiguity between Moab and Israel. The boundaries are also porous - Naomi, Elimelech, and their two sons had no obstacles to relocate to Moab during the famine time (Diamant, 2008, p. 33).

After they dwelt in Moab, his two sons married women from Moab, one is afterwards a devoted daughter-in-law of Naomi whose name is Ruth ("Ruth” means "Comrade, Companion, or Neighbour", see also in Exodus 11:2 in a common setting), and another's name is Orpah (1:3-4). However, unfortunately Naomi was bereft of Elimelech in Moab, and after about ten-year sojourn, Mahlon and Kilion also died in there (1:4-5), leaving the penniless women without a male protector. Rabbinic commentators interpret the death of Elimelech and his 
two sons as a punishment for their intermarries with Moabite women, although the Ruth narrative itself gives no support to this point of view. Therefore, the three widows began to live under one eave.

Then Naomi wanted to dismiss their two daughters-in-law to their own parents' homes, but Ruth and Orpah still weighted their responsibility to the family. Finally, Orpah accepted the advice to go back, but Ruth refused despite Naomi's resistance (1:14) and consistently showed her loyalty (1:16-17).

When referring to the narrative of the book, Ruth's Moabite origins indicate tensions between endogamy (the custom of marrying only within the limits of a local tribe or clan) and exogamy (the custom of marrying outside a tribe or clan). For example, Fewell and Gunn (1988; 1990, p. 74) interpreted that in this ostensibly idealized narrative of selfless devotion, Naomi's request for her two daughters-in-law three times to "return" to their own mothers' home $(1: 8,11,12)$ and one more time repeat to Ruth's audacious statement indicates not only her self-centeredness, but also her unease at Ruth's Moabite origins and desire to identify with God of Israel and Naomi's community. In fact, Ruth's possible reasons to convert and to reluctant to return to her kin have been an important topic of discussion among rabbinic commentators that focuses on her show of loyalty to her mother-in-law, or on just her determined overstatement for the sake of her future, or a combination of both impulses. However, more than others in the Bible, the book of Ruth illustrates the possibility of integration of the foreigner into the in-group of Israelite society through a process of several stages of acceptance. Even in some situations such as Naomi's coming back from Moab to her hometown are usually in the first beginning portrayed as being estranged from her own Israelite society. The process of reintegration is usually progressive and sometimes needs help of themselves and others, for example, Ruth's efforts on her behalf and Boaz's assistance (Diamant, 2008, pp. 31-32).

Once a time when barley harvest, a symbol of life, began in Bethlehem, Ruth accompanied Naomi back to Naomi's hometown (1:19). They were actually challenged upon their return to Bethlehem from Moab since there was no unopposed censure directly against Naomi when she returned to the land of Judah and her hometown Bethlehem by companied with Ruth (Diamant, 2008, p. 33). When entering into her hometown, Naomi declined the women of the town calling her Naomi, but preferred to be called Mara ("Mara” means "Bitterness") since she 
explained to the Bethlehem women that the Almighty had made her present condition of very sorrow and had given her so much trouble $(1: 20-21)$.

At that time Israel's farmers abided by an ancient custom stemmed from some God's rules as concerns leaving grain for poor and travelling people, orphans, and widows when harvesting (Leviticus 19:9-10; see also Leviticus 23:22 and 24:19-22). Therefore, Ruth involuntarily went to glean crops in the field which was belonged to Boaz [the etymology of "Boaz" means "in the strength of" or "in him (is) strength", and "Boaz" appears also as the name of one of the two bronze pillars erected at the north of the entrance to Solomon's temple (1 Kings 7:21-22; 2 Chronicles 3:15-17, Freedman, 1992a, p. 765)] who was an influential landowner in Bethlehem and also from the clan of Elimelech's family (2:1-3). When Ruth came home with a very large load of grain and told Naomi about Boaz's respect to his hired workers (2:4), compassion (2:5-6), and protection (2:8-9, 14-16) for her, Naomi was very happy and called Boaz a "Kinsman-redeemer" (2:20) since she knew that Boaz was a close relative of them and has legal responsibility to care for the two poor widows. Freedman (1992b) deduces that "the familial relationship between Naomi's husband and Baoz must have been distant since Naomi did not know of him until her return to Bethlehem (1:8-16; with 2:20)". However, after rereading the above verses as well as 3:2,10, it is credible that both Naomi and Boaz knew their clan relationship before Naomi and Ruth returned to Bethlehem. Therefore, though destitute, Naomi and Ruth still survived as the aid of Boaz.

One day Naomi gave Ruth some advice on how she can approach to Boaz (3:1-4) so that he can marry Ruth and therefore can fulfil as a family protector of them. Since Boaz knew that he is not first in line to marry Ruth as her kinsman-redeemer, he decided in the next morning to negotiate with another unnamed kinsman-redeemer whose clan relationship is closer to Elimelech than Boaz (3:12-13). At the city gate, Boaz gathered the close relative and ten of the older leaders, and told them about buying Naomi's land (4:3-4) since according to the principle of proximity on inheritance in the recorded law (Numbers 27:1-11), Naomi had right to inherit her husband's property. Along with the land property, Boaz also reminded that closest kinsman-redeemer that he has obligation to "acquire the dead man's widow" (4:5), Ruth, "in order to maintain the name of the dead with his property" (4:5). Upon hearing of this obligation, the relative closer to Elimelech realized 
that he has to pass his inheritance mixed up with Elimelech's land onto Ruth's children. Then he released his legal claim to Elimelech's property (4:6-8). So Boaz acquiesced his legal responsibility, willingly took Ruth as his wife for the purpose of "maintain the name of" her deceased husband Mahlon (4:10), and purchased a parcel of land offered for sale by Naomi (4:3, 9-10). After that, the elders affirmed the contract and blessed the marriage of Boaz and Ruth (4:11-12).

In general, the book of Ruth relates the restoration of seed: famine and food for Naomi and Ruth, a husband for Ruth, a redeemer and rehabilitation for Naomi, and an heir leading to a King for the whole people (e.g., Green, 1982; Webb, 2000, p. 43). The book also demonstrates women redeeming their own salvation with fear and trembling, for which God works among them (Freedman, 1992c).

\section{Leadership characters in the Book of Ruth}

\subsection{Naomi - My Pleasantness}

Naomi's leadership characters which are derived from her and Ruth's dialogues incorporate loyalty to God (2:19-20), discovering inside value (3:1-4), and patience and endurance (3:18).

As for Naomi's leadership character of loyalty to God, although shaking on her faith once in Moab, she still trusted in God after coming back to the land of Bethlehem and blessed the man who took notice of Ruth in the name of God.

As for Naomi's leadership character of discovering inside value, when Naomi heard that Ruth was gleaning in her kinsman-redeemer's field and that the kinsman-redeemer treated Ruth so well, Naomi discovered the so-called inside value or concretely to say, Boaz's responsibility as their "family protector". Naomi's initiation was a bold, even scandalous, albeit valuable plan in order to secure a home for Ruth. It is noteworthy that according to the law (Deuteronomy 25:5-10), a brother should marry his brother-in-law's widow rather than the widow's daughter-in-law. While at here, Naomi planned to let Ruth approaching to Boaz rather than herself. One approach assumes that since Naomi and Elimelech already had two sons, although they died, but Ruth and Mahlon did not have any child. Therefore, Ruth should be replaced as the widow instead of Naomi (B. Adamczewski, personal 
communication, October 28, 2015). However, it is convincing that since Naomi was very old and that Ruth was still young at that time, so it would have more probabilities to persuade Boaz to marry Ruth than Naomi.

As for Naomi's leadership characters of patience and endurance, though in the beginning her plot was a dangerous mission for Ruth to seduce Boaz (3:1-4) instead of requesting a permanent, legal union with men (see Berger, 2009 for a discussion), just as Tamar and Lot's daughters seduced an elderly kin member in order to become the mother of his offspring, Naomi closed it by counselling a patient wait with endurance (3:18).

However, Naomi was also fluctuated of her faith to God when she and her daughters-in-law stayed in Moab (1:13). She believed that her loss of her husband and her two sons after fleeing from their home since "the Lord's hand has gone out against me!" (3:18d). Comparing with censure of Job's doing evil by his friends (Job 4:8ff) and the Apostles' thought of the man born blind of his sins (John 9:1ff.), most people wrongly attribute the suffering or losses to the punishment from the hand of God. Naomi simply also put her emphasis on earthly prosperity (1:11ff), but otherwise not like Ruth, Naomi neglected what her leaning of her heart should be towards the God of Israel.

\subsection{Ruth - a faithful follower as well as a pioneer}

Ruth's leadership characters which are derived firstly from her and Naomi's dialogues include faithfulness and positive self-esteem (1:16-17), pioneer and daring (2:2), deference (2:10), and obedience (3:5), and secondly from her and Boaz's dialogues incorporate loving-kindness (3:10).

As for Ruth's leadership character of faithfulness, though Naomi insisted, even until Orpah agreed (1:9-14), Ruth still extraordinarily decided to stay, pledging allegiance to Naomi even beyond death (1:16-17). Ruth's faithfulness also manifests in that even when Naomi from Israel vacillated her faith towards God, Ruth a Moabite still inclined to trust on her married relation and probably God to Whom Naomi and Elimelech have influenced Ruth's faith to build together their faithful relationship.

As for Ruth's leadership character of positive self-esteem, she insists on staying with her mother-in-law no matter wherever she wants to go 
since Ruth still hopes to show her worthiness and satisfaction in relationship with Naomi. Ruth's positive self-esteem could also aspire her leadership, which manifests later in the Narrative. Nowadays, modern studies have also demonstrated such a positive relationship between self-esteem and levels of leadership aspirations (e.g., Mason, Mason, and Mathews, 2016).

As for Ruth's leadership characters of pioneer and deference, she came to Boaz's fields to glean grain by choice as well as by chance - perhaps a sign of deity providence (2:3), and she appropriately exclaimed to Boaz deferentially.

As for Ruth's leadership character of daring, her initiative to pick up the leftover grain leaded her mother-in-law Naomi together conquering their predicament and embracing the gift of food. Besides, instead of Boaz telling her what to do (cf. 3:5), inversely, she advised Boaz to "spread the corner of your garment over me, since you are a kinsman-redeemer” (3:9c).

As for Ruth's leadership character of obedience, like the lily in the field and the bird of the air (Matthew 6:26, 28), she was unconditionally agreed to her mother-in-law Naomi's plan to marry Boaz and therefore submitted to God's will, even though she was free of family obligations.

As for Ruth's leadership character of loving-kindness, she acted in ways that promote the well-being of others, for example, by deciding not going back to Moab but accompanying Naomi to a foreign land and by accepting the lower social status of the job to glean from the field (Sakenfeld, 1999, pp. 11-12). Besides, Boaz appreciated her and said to her that "this kindness is greater than that which you showed earlier: You have not run after the young men, whether rich or poor” (3:10b).

\subsection{Boaz - an example of covenant fidelity}

Boaz's leadership characters which are derived firstly, from his and Ruth's dialogues comprise compassion (2:8-9, 11), leaning on and trusting God (2:12), care (2:14; 3:15), protecting the weak (3:10-15), responsibility (3:12), moral integrity and justness (3:13), and carefulness (3:14), secondly, from his and the harvesters' dialogues incorporate respect (2:4), care (2:5), and empowerment (2:15-16), thirdly, from his and the nearer kinsman-redeemer' dialogues include formation (4:1), unselfishness, and cleverness (4:3-5), and fourthly, from his and the elders' dialogues contain partnering (4:9-10). 
As for Boaz's leadership character of compassion, apparently Boaz's tremendous power was subservient to the women's story. Therefore, he requested Ruth to stay, gave her food, and also ordered his men to cooperate.

As for Boaz's leadership character of leaning on and trusting God, his unwitting blessing to Ruth showed his loyalty and trust to God, and he wished that her payment "be richly rewarded by the Lord, the God of Israel” (2:12b). During the Judges period that Boaz lived in, though a broader disregard of God's laws was deeply rooted among people ("In those days Israel had no king; everyone did as he saw fit”, Judges 21:25), as among others a few faithful people, Boaz occupied a noble plain.

As for Boaz's leadership characters of caring others and protecting the weak, he cared for Ruth, Naomi, and his harvesters and protected Ruth from other men.

As for Boaz's leadership character of responsibility, though there was no clear compulsorily legal obligation upon Boaz to fulfil a kinsman-redeemer's responsibility to a childless widow with the law of the levirate (Deuteronomy 25:5-10), he still abided by the law as well as the customs of the Pentateuch with regard to redeeming person (Leviticus 25:47-53), that is if a married man died without having any children, one of his male relatives were supposed to marry his widow so that she would have children in her dead husband's name. In addition, according to the customs of the Pentateuch with regard to redeeming property (Leviticus 25:25; 27:9-25), the dead man's inheritance can pass on to those children (see also 4:10). Beyond that, when Ruth requested him to fulfil his kinsman-redeemer's responsibility (3:9c), his response was gracious, promising to "do for you all you ask" (3:11), comparing with Ruth's agreement to do "all” that Naomi asked (3:5).

As for Boaz's leadership character of moral integrity and justness, though we can guess that he felt affection for Ruth, he still allowed another relative who was closer to Naomi's and Ruth's clan to marry Ruth (3:12-13). In this point, Boaz behaved as a model of godliness and purity. Probably Boaz was a man who had not had a descendant before marring Ruth (cf. comparing with the response of the nearer kinsman-redeemer, 4:6, Freedman, 1992a, p. 765), and eventually Boaz was rewarded with Ruth as a wife and their son Obed for his moral integrity and fairness to comply with commitment. Boaz's fairness serves as a foundation for one of the most important virtuous qualities a public leader should have, justness. 
As for Boaz's leadership characters of respect and formation, he treated his workers respectfully and tenderly, and in reverse, they obviously also respected for Boaz as well (2:4-6). He formed the elders and the nearer redeemer at the gate of the city, where business and legal transactions occurred (4:1-2).

As for Boaz's leadership character of unselfishness, his supreme virtue represents not eventually at his marriage with Ruth, but rather his willingness to not conceal this foil between him and the closer kinsman-redeemer and his putting aside his personal sentiment in order to complete the requirements of the covenant law (Berlin, 1983, p. 86; Freedman, 1992a, p. 765).

As for Boaz's leadership character of cleverness, Boaz cleverly creates an impression at the first beginning of his dialogue with his relative that the redemption concerns only the property, not Ruth, while afterwards at the right moment includes Ruth in the transaction (Hubbard, 1988, p. 241). Finally, Boaz smartly unfolds the complicated legal process of the custom to find a kinsman-redeemer to marry Ruth step-by-step and then legally obtains Ruth as his wife.

\subsection{Elimelech - a spiritual adventurer}

In the famine time, Elimelech's strategy of taking his family to a pagan country is an adventure for his two sons' faith especially when the two sons were of marriageable age. The result verifies that Mahlon and Kilion married Moabite women. Usually under circumstances of mixture marriage between Israel and pagan, these pagan wives or husbands would have a great influence upon their spouses, running almost always to the point of leading them away from the faith towards God. Fortunately, Ruth and Orpah are believed to be kind, good, and loving, and no evidence suggests that they are wicked and should be responsible for their husbands' deaths.

\section{Discussion and conclusion}

The current paper is about a glimpse at the general guideline on leadership characters in the Bible and a detailed synopsis on leadership characters in the book of Ruth. First, by exemplifying some elements of servant and mentoring leadership and Biblical figures’ pious leadership 
traits, we attempt to build up a basic concept on leadership characters from the Biblical point of view (cf. Kessler, 2013 argued that constructing "pure" Biblical leadership is a pitfall). Second, we hope to establish the modern servant and mentoring leadership characters by referencing those important Christian leadership characters that have been rooted for thousands years from the Bible to the contemporary time. Third, we also seek to give Biblical evidence for reconstructing Christian leadership characters' theories. Fourth, the book of Ruth suggests that successful mentor relationships result in benefits both to the mentor and the protégé. It suggests that by following the similar tutorial mode, leaders in today can also build mentor relationships that prepare them to handle the challenges tomorrow. Fifth, it is noteworthy that although the current paper's discussion mainly limits within the Biblical point of view, the secular concepts of leadership characters can also find their way into the Biblical norms and vice versa (see Wessels, 2003 for a discussion on incorporating secular leadership achievements into churches). At here we also argue that it is justifiable for a leader to use insights from other sources since the Bible is not a handbook on leadership.

It is also noteworthy that God created men and women to serve a different, albeit complementary leadership role. In the Old Testament time, the general rule was that the men should play a leadership role both in their families and in a social community, however, that the women should be always affiliated to men and should not exercise public functions (Grzywaczewski, 2012, p. 27). Sadly, the prevailing theological hierarchical system (God, Christ, Man, Woman) actually has not changed too much until now, and even the doctrines derived by the patristic-oriented interpretations, for example, from the Apostle Paul (e.g., 1 Corinthians 11:2-3; 1 Timothy 2:11-15, 3:2, 3:12; Titus 1:6), have been consistently misused to foster racial discrimination and to regulate women's leadership role in family and church life (for a discussion on the leadership roles of the feminine, see Inyamah, 2008). However, some scholars and church clergies have appealed to anoint women's subordinate social status as equal as men's (e.g., Frantz and Silver, 1985). Typically, if we compare the book of Ruth with others in the Bible, we cannot find any other one in which women's initiative activities and dialogues to men in the society are more rich than the Ruth Narrative (for other narratives of women leadership in the Bible, see e.g., Prophet and Judge Deborah in Judges 4-5 and Prophet Huldah 
in 2 Kings 22:14-20 and 2 Chronicles 34:22-28). Therefore, we believe that God would like to stress the affirmation of women leadership in the Bible.

In conclusion, through understanding the impact of the social and cultural environment on the pious figures in the book of Ruth, a faithful Christian can imitate them to live out the Holy Scripture's message by their good examples. On the other hand, although Naomi and Ruth sank into the "everydayness" of their plight, their leadership characters helped them to grow up and to become leaders and servants of God. Through the story, as for Naomi, it gives an insight that mothers need to take good care of their families and to encourage their family members to conduct appropriate action on behalf of their benefits. Naomi's leadership characters also remind us that a good family mentor needs to strike a balance between giving advice and encouraging initiative on the part of those being mentored. As for Ruth, the devotion of the daughterin-law is also an ideal example of loving her family. Boaz's acting role is just like the Apostle Paul's metaphor "head" in Ephesians 5:23 which emphasizes on a leader's responsibility and service-focused relationship rather than indicating an authority differential of male hierarchy over women and slavery (Cohick, 2012). As an exemplar of excellent leadership, Boaz bore in mind his responsibility to take care of the two widows belonging to his clan and also served them wholeheartedly. These passages further providing some ethical guidelines for public leaders to carry out their duties in order to honour God.

Meaningfully, when comparing Ruth with the narratives of Lot's daughters in Genesis 19 and Judah and Tamar in Genesis 38, the book of Ruth is seen as the culmination of the trajectory from the illicit and as the illegitimate to the scrupulously legal and legitimate (Fisch, 1982). Ruth not only chooses Israel and its God, but is also chosen by God to speak His word to Israel. Through the marriage between a descendant of Judah, Boaz, and a Moabitess, Ruth, they begat Obed, the grandfather of David (4:13, 18-22). Therefore, Boaz's name could appear in the honoured seventh place in the ten-name royal genealogy of David (4:18-22) and also in the royal line of David by the Chronicler (1 Chronicles 2:11-12). Besides, because of Boaz's and Ruth's relationship to the Davidic house, they are also in the ancestral lineage of Jesus Christ (Luke 3:32). Moreover, God's graceful covenant of salvation extends to Gentiles through Ruth, a specific ancestress of Christ mentioned in St. Matthew’s Genealogy (Matthew 1:5). 
Acknowledgement: I thank Fr. Prof. Bartosz Adamczewski and Fr. Prof. Janusz Kręcidło both at the Faculty of Theology, Cardinal Stefan Wyszyński University in Warsaw, the editor, and the two anonymous reviewers for comments on earlier drafts of this article.

\section{Bibliography}

Berger, Y. (2009), “Ruth and Inner-biblical Allusion: The Case of 1 Samuel 25”, Journal of Biblical Literature, Vol. 128, No. 2, pp. 253-273.

Berlin, A. (1983), Poetics and Interpretation of Biblical Narrative, Sheffield.

Cohick, L.H. (2012), “Tyranny, Authority, Service: Leadership and Headship in the New Testament”, Ex Auditu, Vol. 28, pp. 74-89.

Diamant, S. (2008), Group Identity in the Hebrew Bible: Moab as a Case of Israelite Self-identity, Ph.D. dissertation, The Jewish Theological Seminary.

Fewell, D.N., Gunn, D. (1990), Compromising Redemption: Relating Characters in the Book of Ruth, Westminster/John Knox Press, Louisville.

Fewell, D.N., Gunn, D.M. (1988), “"A Son is Born to Naomi!»: Literary Allusions and Interpretation in the Book of Ruth", Journal for the Study of the Old Testament, Vol. 13, No. 40, pp. 99-108.

Fisch, H. (1982), "Ruth and the Structure of Covenant History", Vetus Testamentum, 42, pp. 425-437.

Frantz, N.P., Silver, D.L. (1985), “Women in Leadership: A Theological Perspective”, Brethren Life and Thought, Vol. 30, pp. 37-40.

Freedman, D.N. (1992a), The Anchor Bible Dictionary. Vol. 1, Doubleday, New York. Freedman, D.N. (1992b), The Anchor Bible Dictionary. Vol. 4, Doubleday, New York. Freedman, D.N. (1992c), The Anchor Bible Dictionary. Vol. 5, Doubleday, New York. Green, B. (1982), “The Plot of the Biblical Story of Ruth”, Journal of the Study of the Old Testament, Vol. 7, No. 23, pp. 55-68.

Grzywaczewski, J. (2012), Prayer of God's Friend According to Clement of Alexandria, Polihymnia, Lublin.

Hoehl, S.E. (2011), “The Mentor Relationship: An Exploration of Paul as Loving Mentor to Timothy and the Application of this Relationship to Contemporary Leadership Challenges”, Journal of Biblical Perspectives in Leadership, Vol. 3, No. 2, pp. 32-47.

Hubbard, R.L.Jr. (1988), The New International Commentary on the Old Testament: The Book of Ruth, William B. Eerdmans Publishing, Grand Rapids, MI.

Huizing, R.L. (2011), "Bringing Christ to the Table of Leadership: Moving Towards a Theology of Leadership”, The Journal of Applied Christian Leadership, Vol. 5, No. 2, pp. 58-75.

Inyamah, D.C. (2008), "Contrasting Perspectives on the Role of the Feminine in Ministry and Leadership Roles in John 4 and 1 Timothy 2:11-15”, Journal of Religious Thought, Vol. 60, pp. 87-108.

Irving, J.A. (2011), “A Model for Effective Servant Leadership Practice: A Biblically-consistent and Research-based Approach to Leadership, Journal of Biblical Perspectives in Leadership, Vol. 3, No. 2, pp. 118-128.

Kessler, V. (2013), “Pitfalls in Constructing ‘Biblical’ Leadership”, Verbum et Ecclesia, Vol. 34, No. 1, Art. \#721, 7 pages. 
McNeal, R. (2011), A Work of Heart: Understanding How God Shapes Spiritual Leaders, Jossey-Bass, San Francisco.

Mason, C., Mason, K., Mathews, A. (2016), “Aspiring to Lead: An Investigation into the Interactions Between Self-esteem, Patriarchal attitudes, Gender, and Christian Leadership”, Journal of Psychology and Theology, Vol. 44, Fall, pp. 244-256.

Niewold, J. (2007), "Beyond Servant Leadership”, Journal of Biblical Perspectives in Leadership, Vol. 1, No. 2, pp. 118-134.

Roberts, G.E. (2015), Christian Scripture and Human Resource Management: Building a Path to Servant Leadership through Faith, Palgrave Macmillan, New York.

Sakenfeld, K.D. (1999), Ruth, John Knox Press, Louisville.

Serrano, C. (2014), "Charismatic and Servant Leadership as Seen in King Saul and Young David: An Inner Texture Analysis of 1 Samuel 17:1-58”, Journal of Biblical Perspectives in Leadership, Vol. 6, No. 1, pp. 27-40.

Thomas, D. (2014), "Daniel as an Example of Exceptional Cross-cultural Leadership, Journal of Biblical Perspectives in Leadership, Vol. 6, No. 1, pp. 58-66.

Webb, B. (2000), Five Festal Garments, Apollos, Leicester.

Wessels, W.J. (2003), “Talking Issue with Thoughts on Church Leadership”, Ekklesiastikos Pharos, Vol. 85, pp. 172-188.

Whittington, J.L. (2015), Biblical Perspectives on Leadership and Organizations, Palgrave Macmillan, New York.

Wilkes, C.G. (2008), Jesus on Leadership: The Man with the Miracle Touch, Lifeway Press, Nashville, TN.

Woolfe, L. (2002), The Bible on Leadership, Amacom, New York. 
